\title{
The effectiveness of the nitrification inhibitor dicyandiamide (DCD) for mitigating nitrogen leaching losses from a winter grazed forage crop on a free draining soil in northern Southland.
}

\author{
L C SMITH $^{1}$, T ORCHISTON ${ }^{2}, \mathrm{R}^{\text {M MONAGHAN }}{ }^{2}$ \\ ${ }^{1}$ AgResearch \\ Woodlands Research Station, RD 1, Invercargill \\ ${ }^{2}$ AgResearch Invermay \\ Private Bag 50034, Mosgiel \\ chris.smith@agresearch.co.nz
}

\begin{abstract}
Evidence suggests that the wintering of stock on forage crops is a significant contributor to $\mathrm{N}$ losses from livestock farming. Losses are likely to be exacerbated if crops are grown on shallow free-draining soils types and grazed by dairy cattle. A three-year trial (December 2008 - November 2011) was conducted in northern Southland on a soil classified as having severe vulnerability for nutrient leaching to groundwater. Porous ceramic cups were installed under a brassica crop which was grazed by dairy cows in June each year and the leachate collected regularly for $\mathrm{N}$ analysis. The treatments evaluated were with and without a single application of DCD applied at the time of crop grazing. Concentrations of nitrate- $\mathrm{N}$ in drainage water ranged from $<1 \mathrm{mg} / \mathrm{L}$ initially to a peak of $>40 \mathrm{mg} / \mathrm{L}$ in May 2011. Concentrations of dissolved organic N (DON) also increased from a low initial value $(<4 \mathrm{mg} / \mathrm{L})$ to peak at $48 \mathrm{mg} / \mathrm{L}$ in May 2011. Estimates of mean annual losses of total nitrogen (TN) in drainage to groundwater averaged $81 \mathrm{~kg} \mathrm{~N} / \mathrm{ha} / \mathrm{yr}$ and ranged from $8.5 \mathrm{~kg} \mathrm{~N} / \mathrm{ha}$ in 2009 to $125 \mathrm{~kg} \mathrm{~N} / \mathrm{ha}$ in 2011 . The single post-grazing application of DCD did not significantly reduce nitrate leaching losses.
\end{abstract}

Keywords: winter forage crop, cow urine, nitrate leaching, dicyandiamide, DCD.

\section{Introduction}

There has been a major shift over the past decade from sheep to dairy farming in Otago and Southland, where dairy cow numbers have increased from 315000 in the 1999/2000 season to more than 657000 in 2009/2010 (LIC 2010). This land-use change has raised concerns about the potential environmental impacts of a growing dairy industry. Monitoring by Environment Southland indicates that $\mathrm{N}$ concentrations in all monitored rivers and in $36 \%$ of the region's aquifer monitoring sites are increasing, in some instances to levels close to or above maximum permissible concentrations for safe drinking water (Environment Southland 2010). Dairy cow wintering on grazed forage crops is perceived to have a relatively large environmental footprint, and is of particular concern when it is located in sensitive catchments. This animal management practice normally occurs over a 10 -week period during winter, and is seen as a cost-effective strategy for providing required amounts of winter feed and avoiding animal treading damage to soils and pastures during wet and cool winters in southern New Zealand. Of particular concern is the lack of knowledge of the effects of winter forage crop grazing on free-draining soils susceptible to $\mathrm{N}$ leaching to ground waters. Preliminary research indicates that $\mathrm{N}$ leaching losses from areas used for forage crop grazing during winter may be relatively large (Smith et al. 2008). This greater risk of loss could be partially attributed to the large amounts of mineral $\mathrm{N}$ that may potentially remain in the soil in late autumn following pasture cultivation and forage crop establishment in the preceding spring. Another contributing factor to a high potential for $\mathrm{N}$ loss is the deposition of large amounts of excretal $\mathrm{N}$ onto bare soil when the forage crop is grazed over winter, a period when plant uptake is low and drainage likely to occur.

Recent work in New Zealand, focusing on $\mathrm{N}$ losses from urine-treated lysimeters, has demonstrated the potential benefits of using DCD to reduce nitrate leaching from pastures (Di \& Cameron 2002, 2003). This work has led to the development of commercially available formulations that farmers can apply to pastures (Di \& Cameron 2006; Monaghan et al. 2009). These have been shown to be effective options for reducing $\mathrm{N}$ losses from grazed pasture systems (Monaghan et al. 2009), but their effectiveness in reducing $\mathrm{N}$ leaching from grazed winter forage crop paddocks is unknown. Here we document $\mathrm{N}$ leaching losses from a shallow, free-draining soil used for winter forage crop grazing by dairy cows in northern Southland, and assess the effectiveness of DCD for mitigating these losses. 


\section{Methods}

The trial was located at Five Rivers in northern Southland. The soil type was a Lintley Orthic Brown soil classified as having severe vulnerability for nutrient leaching to groundwater. This soil is classified as a slightly gravelly silt loam, typically shallow $(<45$ $\mathrm{cm}$ to gravel), free draining and with a water-holding capacity (to $50 \mathrm{~cm}$ ) of $37 \mathrm{~mm}$. Annual rainfall for this area averages $871 \mathrm{~mm}$ (1998-2007 average) and water balance model calculations suggest a drainage depth of $c a .200 \mathrm{~mm} / \mathrm{year}$. The trial was set up in December 2008 with 20 plots pegged out in a first-year swede (Brassica napus) crop. Crop management and yield details are presented in Table 1. Plot size was $10 \mathrm{~m} \times$ $10 \mathrm{~m}$ with 10 replicates of 2 treatments - plus or minus (hereafter referred to as "control") a single mid-winter application of DCD applied following each grazing. The DCD used was a granular zeolite-coated DCD formulation ( $\left.\mathrm{DCn}^{\mathrm{TM}} ; 24 \% \mathrm{DCD}\right)$ which was applied at a rate of $42 \mathrm{~kg} / \mathrm{ha}$, or the equivalent of $10 \mathrm{~kg}$ a.i./ha. The crops were grazed by a mob of dairy cows for between 8 and 10 days in mid to late June each year (See Table 1). During the grazing period the cows were gradually allowed more of the crop so that some plots were grazed on day 1 , whilst others were not grazed until a week later. As the cows were allowed free access to the previously grazed area, excreta deposition to some plots would have been greater than to others.

In summer each year, 10 porous ceramic cups (Webster et al. 1993) were installed in each plot to a depth of $550 \mathrm{~mm}$ (at a 45 degree angle). It was assumed that this density of ceramic cups $(1000 /$ ha) coupled with the high degree of plot replication would be sufficient to overcome the variability and limitations of this method for measuring leaching losses in the field (Lilburne et al. 2012). These cups were removed in early November each year to allow re-cultivation of the site and sowing of the next winter crop, before re-installation for the following winter's leaching measurements. Dates of cup installation for the 3 years of measurement were 24 February 2009, 9 December 2009 and 25 November
2010. Leachate was collected from the porous cups for every $20-25 \mathrm{~mm}$ of excess rainfall, as calculated by a soil water balance model, by applying a suction of $c a .60 \mathrm{kPa}$ overnight and removing all the collected soil solution next day. There were between 10 and 13 leachate samplings each year, with at least two of these samplings occurring before the crop was grazed in June. The leachate collected was frozen for storage

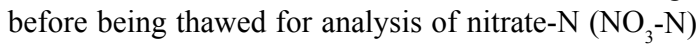
and ammonium- $\mathrm{N}\left(\mathrm{NH}_{4}-\mathrm{N}\right)$. At the end of each drainage season samples were also bulked on a plot basis (3-4 $\mathrm{ml}$ from each cup sample) and analysed for dissolved organic nitrogen (DON), total dissolved nitrogen (TN) and DCD concentration. A daily soil water balance (Monaghan \& Smith 2004) was used to determine total daily surplus water volumes and soil water deficit values at the site. Potential evapotranspiration data were obtained from the Manapouri meteorological station $c a .60 \mathrm{~km}$ west of the study site. Rainfall and soil temperature were continuously monitored at the site and logged using a Campbell Scientific CR10 datalogger.

Following the normal spring cultivation in November 2011, soil samples from the $0-75,75-150,150-300$ and $300-600 \mathrm{~mm}$ depths were collected for mineral $\mathrm{N}$ $\left(\mathrm{NH}_{4}-\mathrm{N}\right.$ and $\left.\mathrm{NO}_{3}-\mathrm{N}\right)$ analysis. Ten cores were collected from each depth per plot, sieved (4-mm mesh width) and mixed before $40 \mathrm{~g}$ was placed in a jar with $200 \mathrm{ml}$ of $2 M \mathrm{KCl}$. This was then shaken for one hour after which the extract was filtered and analysed for $\mathrm{NO}_{3}-\mathrm{N}$ and $\mathrm{NH}_{4}-\mathrm{N}$ concentrations by Flow Injection Analysis. The remaining soil was dried to determine gravimetric soil moisture content.

All data were analysed by ANOVA using GENSTAT for Windows, v13.2. Nitrate and ammonium leaching data were analysed using a split plot analysis, with the individual cups being classified as subplots. Leaching losses for each collection date were calculated using the $\mathrm{N}$ concentrations at that sampling multiplied by the calculated volume of surplus rainfall received since the previous leachate collection.

Table 1. Crop details for the three years of measurement at Five Rivers.

\begin{tabular}{|c|c|c|c|}
\hline & 2009 & 2010 & 2011 \\
\hline Crop & Swede & Swedes + Turnips & Fodder Beet \\
\hline Variety & Sensation & Sensation + G2 & Brigadier \\
\hline Fertiliser applied (kg/ha) & $46 \mathrm{~N} ; 24 \mathrm{P} ; 30 \mathrm{~K} ; 29 \mathrm{~S}$ & 102N; 89P; 0K; 35S & 54N; 89P; 0K; 35S \\
\hline Sowing date & 24 Nov 2008 & 6 Dec 2009 & 23 Nov 2010 \\
\hline Crop yield & 16.7 t DM/ha & 11.8 t DM/ha & 15.2 t DM/ha \\
\hline Crop chemical analysis (\%) & N 1.61; P 0.20; K 1.56; S 0.24 & N 3.52; P 0.31; K 3.08; S 0.52 & N 1.83; P 0.20; K 2.98; S 0.16 \\
\hline Grazing dates & $12-21$ June 2009 & 22 - 28 June 2010 & 24 June - 4 July 2011 \\
\hline DCD application date & 22 June 2009 & 30 June 2010 & 6 July 2011 \\
\hline
\end{tabular}



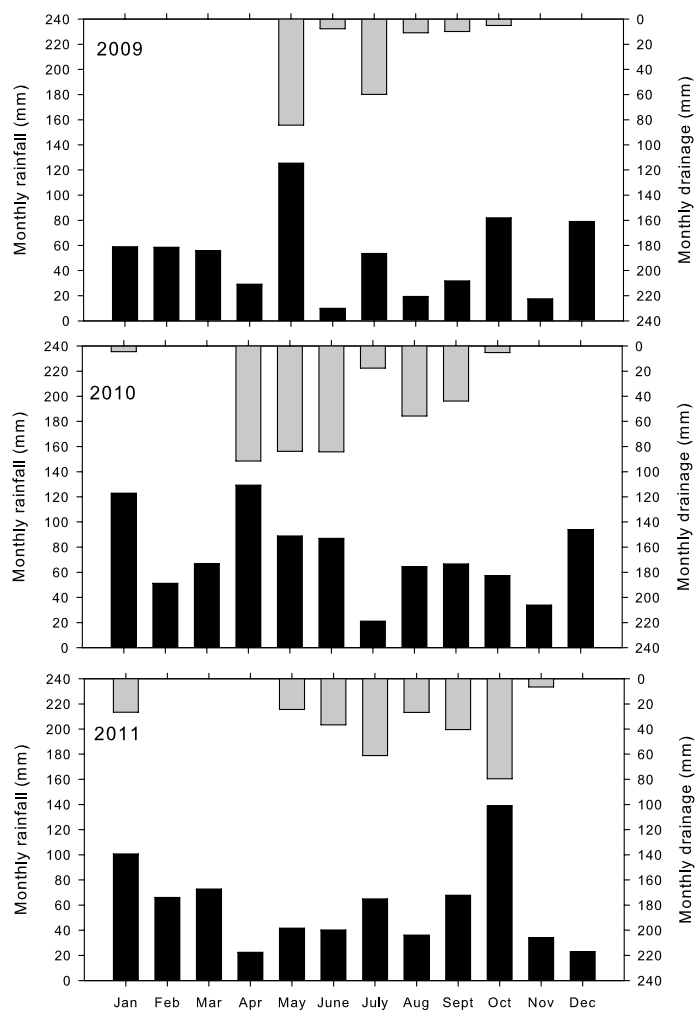

Figure 1. Monthly rainfall $\square$ and drainage totals for the three years of measurements at Five Rivers

\section{Results and Discussion}

The 3 years of the trial were very different in terms of rainfall and drainage patterns (Figure 1). In 2009, the drainage depth $(178 \mathrm{~mm})$ amounted to $29 \%$ of measured rainfall $(621 \mathrm{~mm})$, whereas in both 2010 and 2011 drainage was considerably higher (386 and $306 \mathrm{~mm}$ respectively) and accounted for a greater proportion of the rainfall (44 and $40 \%$ of 883 and $766 \mathrm{~mm}$, respectively). Drainage in 2010 commenced slightly earlier than in 2009 and 2011, and in 2011 the drainage season extended well into the spring period. Although rainfall in July 2009 was similar to that measured in 2011 , the majority (83\%) of it occurred late in the month, approximately one month after DCD application. In contrast, rainfall in July 2011 was evenly spread over the month. Soil temperatures dropped from a summer high of $15^{\circ} \mathrm{C}$ to be at their lowest in mid-winter when the DCD was applied (Figure 2). Soil temperatures in July and August 2011 were $1-2^{\circ} \mathrm{C}$ lower than measured for these months in 2009 and 2010.

Nitrate-N $\left(\mathrm{NO}_{3}-\mathrm{N}\right)$ concentrations in leachate increased steadily from a low of $c a .<1 \mathrm{mg} / \mathrm{L}$ in 2009

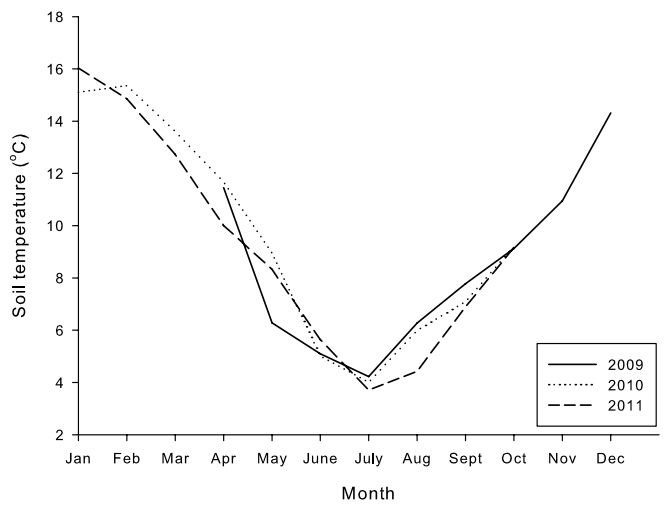

Figure 2. Average monthly $10-\mathrm{cm}$ soil temperatures for the three years of measurement at Five Rivers

to reach $13 \mathrm{mg} / \mathrm{L}$ in the control treatment and $11 \mathrm{mg} / \mathrm{L}$ in the DCD treatment when the cups were removed in October 2009 (Figure 3). However, following the cultivation and sowing of the second crop there was a sharp increase in $\mathrm{NO}_{3}-\mathrm{N}$ concentration, reaching a peak of 27 and $21 \mathrm{mg} / \mathrm{L}$ in leachate collected during January 2010 for the Control and DCD treatments, respectively. Concentrations then dropped before rising again in early June. Following the crop grazing in 2010 , concentrations increased from $20 \mathrm{mg} / \mathrm{L}$ for the control treatment and $19 \mathrm{mg} / \mathrm{L}$ for the DCD treatment to reach 28 and $21 \mathrm{mg} / \mathrm{L}$ respectively by late October 2010. Nitrate-N concentrations peaked in May 2011 for the control treatment at $34 \mathrm{mg} / \mathrm{L}$ and for the DCD treatment at $44 \mathrm{mg} / \mathrm{L}$. Following crop grazing, $\mathrm{NO}_{3}-\mathrm{N}$ concentrations steadily declined to be below $11 \mathrm{mg}$ $\mathrm{N} / \mathrm{L}$ by October 2011. Concentrations of $\mathrm{NH}_{4}-\mathrm{N}$ were much lower than observed for $\mathrm{NO}_{3}-\mathrm{N}(<0.5 \mathrm{mg} / \mathrm{L})$, and tended to be higher following grazing or cultivation before dropping rapidly (Figure 3 ). These spikes were particularly evident immediately following the crop grazing in 2009, and one month after the crop grazing in 2011.

Concentrations of DON were relatively low initially $(<4 \mathrm{mg} / \mathrm{L})$ and increased slightly after grazing in June 2009 (Figure 4). As observed for $\mathrm{NO}_{3}-\mathrm{N}$, DON concentrations increased to $17-20 \mathrm{mg} / \mathrm{L}$ in January 2010 following the cultivation and re-sowing of the crop. Following this peak, concentrations dropped to relatively low levels $(<3 \mathrm{mg} / \mathrm{L})$, where they remained for the whole of 2010. The largest change in DON concentration was the large increase measured in summer and autumn 2011. Concentrations peaked at $48 \mathrm{mg} / \mathrm{L}$ in early May before dropping to less than 15 $\mathrm{mg} / \mathrm{L}$ in spring drainage. Concentrations of TN steadily increased during the trial, peaking at $80-90 \mathrm{mg} \mathrm{N} / \mathrm{L}$ in May 2011. 


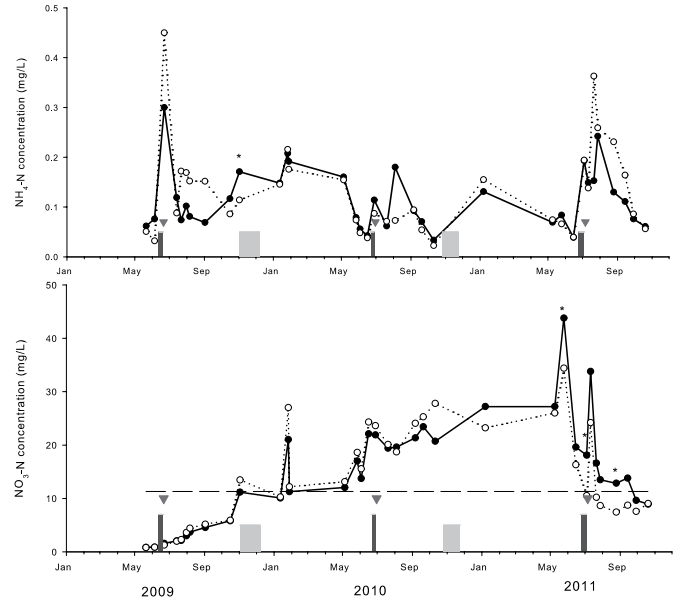

Figure 3. Concentrations of ammonium $\mathrm{N}\left(\mathrm{NH}_{4}-\mathrm{N}\right)$ and nitrate $\mathrm{N}\left(\mathrm{NO}_{3}-\mathrm{N}\right)$ in leachate collected from the control $(\bigcirc)$ and DCD $(\bullet)$ treatments. The dashed horizontal line indicates the drinking water standard of $11.3 \mathrm{mg} \mathrm{N} / \mathrm{L} ; \square$ indicates the time of grazing of the crop; indicates the timing of cultivation of the trial; and $\mathbf{\nabla}$ indicates the timing of DCD applications. Significant $(\mathrm{P}<0.05)$ differences are indicated by an asterisk.
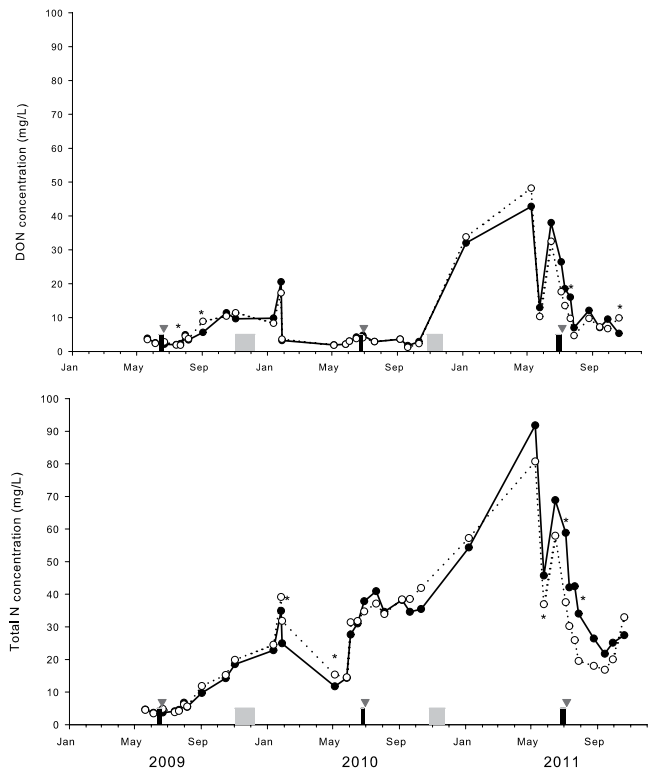

Figure 4. Concentrations of dissolved organic $\mathrm{N}(\mathrm{DON})$ and total dissolved $\mathrm{N}(\mathrm{TN})$ in leachate collected from the control $(O)$ and DCD $(\bullet)$ treatments. indicates the timing of grazing of the crop, indicates the timing of cultivation of the trial and $\boldsymbol{\nabla}$ indicates the timing of DCD applications. Significant differences are indicated; ${ }^{*}=\mathrm{P}<0.05$.

Table 2. Estimated annual losses of $\mathrm{N}$ and DCD in drainage waters from the winter-grazed forage crops (kg/ha). The F-statistic is given for the comparison of treatment means (bold if significant) together with the least significant difference at the $\mathrm{P}<0.05$ level of significance.

\begin{tabular}{|c|c|c|c|c|c|c|}
\hline Treat & $\mathrm{NH} 4$ & $\mathrm{NO3}$ & DON & $\mathrm{TN}$ & DCD & TN lost prior to grazing \\
\hline \multicolumn{7}{|l|}{2009} \\
\hline Control & 0.17 & 2.7 & 5.6 & 8.5 & 0.0 & $2.2(26 \%)$ \\
\hline DCD & 0.13 & 2.4 & 5.9 & 8.5 & 0.4 & $2.3(27 \%)$ \\
\hline F-statistic & 0.643 & 0.308 & 0.576 & 0.978 & 0.003 & 0.709 \\
\hline $\operatorname{LSD}_{0.05}$ & 0.19 & 0.6 & 1.3 & 1.9 & 0.2 & 0.5 \\
\hline Reduction due to DCD & $24 \%$ & $11 \%$ & & $0 \%$ & & \\
\hline \multicolumn{7}{|l|}{2010} \\
\hline Control & 0.31 & 108 & 13.0 & 122 & 0.0 & $65(53 \%)$ \\
\hline DCD & 0.34 & 99 & 13.7 & 113 & 0.7 & $57(50 \%)$ \\
\hline F-statistic & 0.277 & 0.378 & 0.509 & 0.452 & 0.002 & 0.195 \\
\hline $\mathrm{LSD}_{0.05}$ & 0.05 & 24 & 2.4 & 26 & 0.4 & 13 \\
\hline Reduction due to DCD & $-10 \%$ & $8 \%$ & & $7 \%$ & & \\
\hline \multicolumn{7}{|l|}{2011} \\
\hline Control & 0.39 & 58 & 45 & 103 & 0 & $40(39 \%)$ \\
\hline DCD & 0.34 & 71 & 47 & 119 & 3.75 & $44(37 \%)$ \\
\hline F-statistic & 0.638 & 0.184 & 0.640 & 0.262 & 0.002 & 0.439 \\
\hline $\mathrm{LSD}_{0.05}$ & 0.23 & 22 & 10 & 301 & 2.0 & 11 \\
\hline Reduction due to DCD & $12 \%$ & $-26 \%$ & & $-16 \%$ & & \\
\hline \multicolumn{7}{|l|}{ Mean } \\
\hline Control & 0.29 & 57 & 21 & 78 & 0.0 & $36(46 \%)$ \\
\hline DCD & 0.27 & 59 & 22 & 80 & 1.6 & $35(44 \%)$ \\
\hline F-statistic & 0.685 & 0.760 & 0.548 & 0.700 & $<0.001$ & 0.656 \\
\hline $\mathrm{LSD}_{0.05}$ & 0.11 & 9.6 & 4.0 & 13 & 0.7 & 6.7 \\
\hline Reduction due to DCD & $7 \%$ & $-4 \%$ & & -4 & & \\
\hline
\end{tabular}



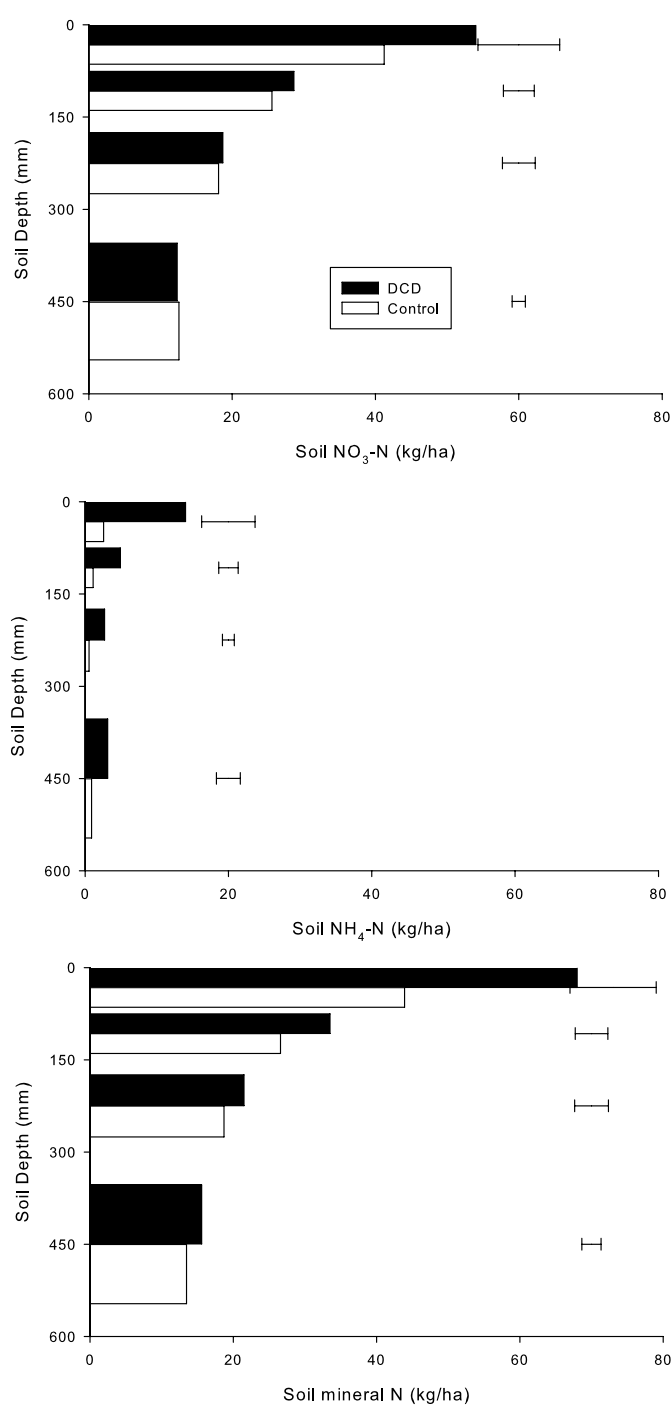

Figure 5. Amounts of nitrate- $\mathrm{N}\left(\mathrm{NO}_{3}-\mathrm{N}\right)$, ammonium- $\mathrm{N}$ $\left(\mathrm{NH}_{4}-\mathrm{N}\right)$, and total mineral $\mathrm{N}$ measured in the 0-75, $75-150,150-300$ and $300-600 \mathrm{~mm}$ soil depth layers in November 2011 following 3 years of winter forage crop grazing. Bars indicate $\mathrm{LSD}_{\mathrm{P}<0.05}$

Estimates of TN losses in drainage averaged $78 \mathrm{~kg} \mathrm{~N} /$ ha/yr (Table 2). Nitrate-N accounted for the majority of the $\mathrm{N}$ leached (89\%) in 2010, whereas DON accounted for the majority of $\mathrm{N}$ leached in 2009 (65\%). Dissolved organic $\mathrm{N}$ and $\mathrm{NO}_{3}-\mathrm{N}$ accounted for similar proportions of $\mathrm{N}$ leached in 2011 (44 and 56\% respectively; Table 2 ). These losses are considerably greater than the $13 \mathrm{~kg} \mathrm{NO}-\mathrm{N} / \mathrm{ha} / \mathrm{yr}$ leached on average from grazed pasture on relatively poorly drained soils in Southland (Monaghan et al. 2009) and Manawatu (Christensen et al. 2011). However neither of these studies reported the amounts of DON leached, and therefore total $\mathrm{N}$ losses are expected to be higher. The losses measured here are similar to those measured under higher $\mathrm{N}(200 \mathrm{~kg} \mathrm{~N} /$ ha/year) inputs to pasture in the Waikato (Ledgard et al. 1999). The single mid-winter application of DCD resulted in small though non-significant reductions in $\mathrm{NO}_{3}-\mathrm{N}$ leaching losses in the first 2 years of the trial (11\% and $8 \%$ respectively), and had even less effect on total $\mathrm{N}$ losses. The reverse was true in 2011 when $\mathrm{N}$ losses from the DCD treatment were slightly greater than those observed for the control treatment though again this result was non-significant. The lack of effectiveness of DCD may be partly attributable to the timings of application with respect to grazing and subsequent drainage events. Some urine deposition occurred up to 12 days before the DCD application and hence may have moved down the soil profile ahead of the DCD. The current commercial recommendation is for DCD to be applied within 7 days of grazing, hence DCD effectiveness may have been improved if the crop was back-fenced and DCD applied sooner to each block as the cows moved across the crop. A relatively large amount of late winter and spring drainage in 2011 may also have limited the effectiveness of the DCD due to transport down the soil profile. The sowing of a cover crop in early spring may be beneficial for capturing some of the remaining soil mineral $\mathrm{N}$ and thus limiting spring drainage losses. Another factor that limited the apparent effectiveness of the DCD treatment was the fact that a considerable proportion of the $\mathrm{N}$ leaching loss (45\% on average; Table 2$)$ occurred prior to crop grazing and DCD application.

An accumulation of mineral $\mathrm{N}$ in the soil profile was observed at the end of the trial (Figure 5). Despite having no significant effect on leaching losses, the single mid-winter application of DCD conserved an extra $34 \mathrm{~kg}$ mineral N/ha, with most of this $(70 \%)$ being in the topsoil $(0-150 \mathrm{~mm})$ and potentially available for uptake by subsequent pastures/crops.

Small amounts of DCD were measured in leachate in 2009 and 2010, with annual losses representing 3-7\% of the DCD applied (Table 2). A large amount of DCD was measured in leachate collected during the winter/ spring of 2011 , representing $38 \%$ of that applied. The reason for this increase in DCD loss is probably due to the higher than normal rainfall and drainage measured in the month following DCD application: $65 \mathrm{~mm}$ in 2011, compared to $33 \mathrm{~mm}$ in 2009 and $13 \mathrm{~mm}$ in 2010 (Figure 1). Indeed, Shepherd et al. (2012) proposed that drainage volume was the main driver of DCD leaching, while Monaghan et al. (2009) reported that losses were largest when there was high rainfall and hence drainage shortly following DCD application. 


\section{Conclusions}

These results demonstrate that leaching losses of $\mathrm{N}$ from winter forage crops grazed by dairy cows on freedraining soils are high relative to losses reported for pastures grazed by dairy cattle. These losses can thus make a disproportionately large contribution to the total dairy system loss relative to the area occupied by winter forage crops. Drainage nitrate-N concentrations increased quickly following winter grazing to exceed the drinking water guideline. Winter forage crops grown and grazed on the same area over successive winters further increased nitrate concentrations. A single mid-winter application of DCD did not significantly reduce nitrate leaching losses, although soil mineral $\mathrm{N}$ measurements taken in November 2011 indicated that DCD application had conserved an additional $34 \mathrm{~kg} \mathrm{~N} /$ ha.

\section{ACKNOWLEDGMENTS}

We gratefully acknowledge the assistance of the many people who helped with the installation of the ceramic cups, Phil Theobald for leachate analysis and Stewart Lindsey for analysis of soil extracts. We also wish to thank Graham Fletcher for allowing us on his property and for the management of the winter grazing. Funding for this project was provided by the Pastoral 21 investors: the NZ Ministry for Science and Innovation, DairyNZ, Fonterra and Meat \& Wool NZ (now Beef + Lamb NZ) (Contract C10X0603). We are also thankful for the financial and in-kind support provided by Environment Southland.

\section{REFERENCES}

Christensen, C.L.; Hanly, J.A.: Hedley, M.J.; Horne, D.J. 2011. Nitrate leaching and pasture production from two years of duration-controlled grazing. In: Adding to the knowledge base for the nutrient manager.Eds Currie, L.D. ; Christensen, C L. http:// flrc.massey.ac.nz/publications.html. Occasional Report No. 24. Fertilizer and Lime Research Centre, Massey University, Palmerston North, New Zealand.

Di, H.J.; Cameron, K.C. 2002: The use of a nitrification inhibitor, dicyandiamide (DCD), to decrease nitrate leaching and nitrous oxide emissions in a simulated grazed and irrigated grassland. Soil Use and Management 18: 395-403.

Di, H.J.; Cameron, K.C. 2003: Mitigation of nitrous oxide emissions in spray-irrigated grazed grassland by treating the soil with dicyandiamide, a nitrification inhibitor. Soil Use and Management 19: 284-290.
Di, H.J.; Cameron, K.C. 2006: Nitrous oxide emissions from two dairy pasture soils as affected by different rates of a fine particle suspension nitirification inhibitor, dicyandiamide. Biology and Fertility of Soils 42: 472-480.

Environment Southland 2010. Our Health: Is our water safe to play in, drink and gather kai from? Part 1 of Southland Water 2010: Report on the State of Southland's Freshwater Environment. Publication number 2010/6. http://www.es.govt.nz/environment/ monitoring-and-reporting/state-of-the-environment/ water-2010/.

Ledgard, S.F.; Penno, J.W.; Sprosen M.S., 1999. Nitrogen inputs and losses from clover/grass pastures grazed by dairy cows, as affected by nitrogen fertiliser application. Journal of Agricultural Science, Cambridge 132: 215-225.

LIC 2010. New Zealand Dairy Statistics, 2009-2010. Livestock Improvement Corporation, NZ. http:// www.lic.co.nz/pdf/DAIRY\%20STATISTICS\%200910-WEB.pdf.

Lilburne, L.; Carrick, S.; Webb, T.; Moir J. 2012. Computer-based evaluation of methods to sample nitrate leached from grazed pasture. Soil Use and Management 28: 19-26.

Monaghan, R.M.; Smith, L.C. 2004. Minimizing surface water pollution resulting from farm-dairy effluent application to mole-tile drained soils II. The contribution of preferential flow of effluent to whole-farm pollutant losses in subsurface drainage from West Otago dairy farm. New Zealand Journal of Agricultural Research 47: 417-428

Monaghan, R.M.; Smith, L.C.; Ledgard S.F. 2009. The effectiveness of granular dicyandiamide (DCD) in limiting nitrate leaching from dairy grazed pastures in Southland. New Zealand Journal of Agricultural Research 52: 145-160.

Shepherd, M.; Wyatt, J.; Welton B. 2012. Effect of soil type and rainfall on dicyandiamide concentrations in drainage from lysimeters. Soil Research 50: 67-75.

Smith, L.C.; de Klein, C.A.M.; Monaghan R.M.; Catto W.D. 2008. The effectiveness of DCD in reducing nitrous oxide emissions from a cattle grazed winter forage crop in Southland, New Zealand. Australian Journal of Experimental Agriculture 48: 160-164.

Webster, D.M.; Shepherd, M.A.; Goulding, K.W.T.; Lord, E.I. 1993. Comparison of methods for measuring the leaching of mineral nitrogen from arable land. Journal of Soil Science 44: 49-62. 